\title{
A qualitative study on the effects of the warning statements on cigarette pockets:A sample of biology education
}

\author{
Cem Gercek $^{\text {1a }}$ \\ ${ }^{1}$ University of Hacettepe, Department of Secondary School Science and Mathematics, Beytepe, \\ Ankara, 06800, Turkey.
}

\begin{abstract}
The aim of this study is to reveal the effects of the written and combined warning statements which are obligatorily covered on cigarette packs on students. The participants of the study were fourteen volunteer undergraduate students. The data of the study were collected through semistructured interview forms. During the interviews the participants were shown cigarette packs with written and combined warning statements. Then they were asked to answer the interview items. The items were developed based on the review of the related literature. Lastly, these items were reviewed by the field experts. These were used in a pilot study on three students. The data gathered were analysed through content analysis.It was found that for participants the effects of the written warning statements were less than those of combined warning statements. However, they also reported that all warning statements were not so influential in quitting smoking. More research is needed on this topic.
\end{abstract}

Keywords. cigarette; cigarette packs, fear appeals; written and combined warning statements; healts education.

\section{Introduction}

Substance which leads to addictive (such as cigarette, alcohol drinks and drugs) is a major social problem whether or not its use is legal. This problem is especially intense in underdeveloped countries. Common use of this substances has negative effects on society in terms of health-care, social, economic and law conditions [2,7].

In Turkey cigarette pockets should include a written warning statement in accordance with the terms of the International Framework Convention on Tobacco Control. The Tobacco and Alcohol Market Regulatory Authority in Turkey identified a total of 14 written warning statements to be added to front and back sides of the pockets.

\footnotetext{
${ }^{a}$ Corresponding author: cgercek@hacettepe.edu.tr
} 
It may be argues that such written warning statements are very significant to avoid using tobacco. Smokers frequently see such statements. Research concludes that a person who smokes a pocket of cigarette per day sees 7000 times these warning statements and that such an encounter may cause a resistance to smoking [5].

In recent studies on high school and university students concluded that although the frequency of the use of addictive substances and cigarette varies based on the geographical regions and the type of substance made, the frequency of use increases $[6,10]$. The aim of this study is to reveal the effects of the written and combined warning statements on the student biology teachers.

\section{Method}

The study is designed as a qualitative research.

\subsection{Participants}

The participants were fourteen volunteer student biology teachers who were attending the fourth grade. The data were collected through the semi-structured interviews.

\subsection{Data collection}

In the interviews a form was used. It was developed by the author based on the review of the related literature. The form is made up of ten open-ended items. Following the review of the interview form by a field specialist the number of the items was reduced to five. The form was used in a pilot study with three student biology teachers to finalize it.

\subsection{Procedure}

The interviews were carried out in the faculty the participants were attending. Each interview lasted about fifteen to twenty minutes. The views of the participants were elicited by showing them various cigarette pockets with written and combined warning statements as well as those without any such statement.

\subsection{Validity and reliability}

The content validity of the data collection tool was reviewed by a measurement specialist and two field specialists. Based on their views the tool was finalized. The data collected were coded by two independent researchers. The consistency between their coding was found to be 0.81 .

\subsection{Data analysis}

The data collected were analysed through content analysis.

\section{Findings}

In this section presents the statements of the participants about the effects of the written and combined warning statements. In regard to smoking habit two participants reported that they smoke. Four of them quit smoking and eight never smoke. Then the participants asked 
how they would be affected from the effects of smoking on other people. Some of the answers to this question are given as follows:

"I asked myself why I smoked when I observed its harms. I lost my uncle and another close relative due to lung cancer, so smoking....People quit smoking especially due to such health-related problems" (Participant-1).

“... My friend's father had lung cancer and died. I thought that I should not smoke anymore. Smoking is like suicide. Many people think that smoking cannot kill me. In general people regard smoking as the cause for bad things" (Participant-2).

"I have been smoking for 3-4 years. Smoking causes a little congestion. When I experience some health-related problems I do not say these are 100 percent the result of smoking. When someone has lung cancer I do not say it is because of smoking. I tried to quit smoking but I could not realize it. I think I will quit it after many trials" (Participant-3).

"...I sometimes smoke. One of my friends, a basketball player, had a problem in his vocal cords and said that it was because of smoking. The most valuable thing for a person is his health. But I still think that smoking is not harmful for me: but, I saw him experiencing problems related to smoking" (Participant -5).

"My grandfather died of lung cancer and he smoked heavily. We always told him not to smoke, but he did not listen to what we. Instead he teld us that cigarette is my long-termfriend. His death was very painful." (Participant-14).

Before asking the remaining the questions to the participants three versions of cigarette pockets (with no warning, with written warning and with combined warning) were shown to them.

"Only one with combined warning statement gives me the message of not smoke. One with written warning has limited effects on me. There should not be red colour on the pockets. Because it is an attractive colour. Instead, black and similar colours should be used" (Participant -2).

"Written warning statements are not influential for me while I am smoking. I get used to see these warnings. However, combined warning statement is really influential. It may help. Written warning statements are not influential at all" (Participant-3).

"Photographs in the combined warning statements are very cool. But it is not so influential. I cannot say that it causes me to quit smoking. I did not smoke for four months, but I began to smoke again." (Participant-4).

"There is no bias in the cigarette pockets with no warning statement. However, some negative bias about smoking should be expressed through cigarette pockets with warning statements. When I see pockets with written warning statements I do not want to buy it. However, those with combined warning statement are very repulsive. Written warnings may have $10 \%$ effects on quitting smoking" (Participant-6).

"... written warning statements show that something is wrong with smoking, but combined warning statements indicate that smoking is really bad... But, I am not sure whether or not these warnings are really influential for smokers. I think combined warning statements are much more influential" (Participant-7).

"I think such statements are very forceful for smokers. Particularly visuals may affect them. They may think about their health or future damages that they may experience because of smoking. However, I do not think these statements are not so influential on addicts. Only they may reduce smoking" (Participant- 8).

"Written statements do not have strong effects. It is important to have such warnings on cigarette pockets. I may say that I did not smoke because of combined warning statements. These statements are forceful, but I do not think written statements are also forceful. They may direct people just to reduce smoking" (Participant-11).

"For the combined warning statements are the most influential one. It is important to have such warnings on cigarette pockets... I showed a cigarette pocket with a written 
warning statement to my friend. He told me that these statements are influential for those who do not smoke. So I think these statements are not forceful for smokers" (Participant12).

"Statements of smoking's harmfulness do not affect smokers. Those who are aware of these damages do not smoke and those who smoke ignore those damages. I am not sure about the effects of written warning statements, but I think combined ones are much more influential" (Participant-13).

\section{Result and discussion}

The WHO reported that addiction is one of the factors that lead to need for care or to catch a disease $[1,9]$.

The participants reported that seeing or knowing the damages of smoking such as lung cancer, cough, shortness of breath, allergies, and problems in the vocal cordsnegatively affects them.

Hymowitzet. al. found that people quit smoking because of health-related problems, the price of cigarette and being a model for family members [4].

After seeing the sample cigarette pockets the participants stated that

- Combined warning statements are cool,

- They learned many new things from written and combined warning statements,

- Written and combined warning statements make the cigarette pockets interesting and disgusting.

Research suggests that written and combined warning statements on cigarette pockets are significant in quitting smoking [8].

It was found that warning statements are also one of the ways to inform non-smokers about the smoking-related health problems. Non-smokers reported that warning statements are remembered by them at a higher level. For instance, in an Austrian study in 2008 it was found that one-third of non-smokers remembered at least one of the combined warning statements on cigarette pockets [3]. All participants stated that of the variants of the warning statements the most forceful one is combined warning statements.

- Five participants stated that combined warning statements may be influential in reducing or quitting smoking.

- Nine participants stated that although warning statements are influential, they did not think that these statements cannot lead to quit smoking.

Research suggests that written and combined warning statements on cigarette pockets are significant in quitting smoking. However, it was found in some studies that neither written statements nor combined statements could not produce desired outcome, namely quitting smoking.For instance, in the study by Özkayaet. al. the students participated in the study regarded warning statements as an important step to reduce smoking. However, they also found that $22 \%$ of the students stopped smoking after reading these statements, but $44 \%$ only influenced by them and 33\% were not affected from these statements and continued to smoke [8].

This finding suggests that warning statements have social effects and that these statements should contain some society-specific elements to increase their desired effects. For instance, forceful warning statements in one country may not have desired effects in other countries [3].

In the study it was found that participants regarded warning statements as not so much influential on avoiding smoking.

Therefore, the effects of warning statements should be analysed on larger and distinct samples in terms of design and content. 


\section{REFERENCES}

1. Bruvold, W. H., A-Meta Analysis of Adolescent Smoking Prevention Programs, American Jounal of Public Health, 83(6), 872-880, (1993).

2. Devlin E, Anderson S, Hastings G. Targeting Smokers With Tobacco Warning Labels - Opportunities And Challenges For Pan European Health Promotion. Health Promotion International, 20(1), 41-49, (2005).

3. Hammond, D. Health Warning Messages On Tobacco Products: A Review. Tobacco Control, 20, 327-337, (2011).

4. Hymowitz N, Cummings KM, Hyland A, et al. Predictors of smoking cessation in a cohort of adult smokers followed for five years. Tobacco Control, 6, 57-62, (1997).

5. Jha, P. and Peto, R. Global Effects of Smoking, of Quitting, and of Taxing Tobacco. The New England Journal of Medicine. 370(1), 60-68, (2014).

6. Kaya, N. ve Çilli, A., Üniversite Öğrencilerinde Nikotin, Alkol ve Madde Bağımlılı̆̆ının 12 Aylık Yaygınlığı, Bağımlılık Dergisi, 3(2): 91-97, (2002).

7. Kees J, Burton S, Andrews JC and Kozup, J. Understanding How Graphic Pictorial Warnings Work On Cigarette Packaging. Journal of Public Policy and Marketing, 29(2),115-126, (2010).

8. Özkaya, Ş., Edinsel, Ş., Özkaya, E. ve Hamzaçebi, H. Sigara Paketleri Üzerinde Yer Alan Yeni Uyarı Yazılarının Lise Öğrencileri Üzerinde Etkileri. Tüberküloz ve Toraks Dergisi; 57(3): 327-332, (2009).

9. Tobler, N. S., ve Stratton, H. H., Effectiveness of School-Based Drug Prevention Programs: A Meta-Analysis of the Research, The Journal of Primary Prevention , 18(1), 71-128, (1997).

10. Ünlü, M., Orman, A., Cirit, M, Demirel, R., Afyon'da Lise Öğretmenlerinin Sigara İçme Alışkanlığı ve Sigaraya Karşı Tutumları, Solunum Hastalıkları, 13: 203-207, (2002). 